\title{
PENGARUH MODAL KERJA DAN RESIKO KREDIT TERHADAP PROFITABILITAS PADA PT. BANK MANDIRI (PERSERO) TBK
}

\author{
Kulsum \\ Program Studi Manajemen Sekolah Tinggi Ilmu Ekonomi (STIE) Bima \\ kulsumalaydrusstiebima@gmail.com \\ Puji Muniarty \\ Program Studi Manajemen Sekolah Tinggi Ilmu Ekonomi (STIE) Bima \\ puji.stiebima@gmail.com
}

\begin{abstract}
Abstrak: Pengaruh Modal Kerja dan Resiko Kredit Terhadap Profitabilitas PT. Bank Mandiri (Persero) Tbk. Penelitian ini bertujuan untuk mengetahui pengaruh modal kerja dan resiko kredit terhadap profitabilitas. Jenis penelitian ini merupakan penelitian asosiatif secara kuantitatif. Sampel penelitian yang digunakan selama 10 tahun. Sampel diambil menggunakan teknik purposive sampling. Metode analisis yang digunakan yaitu analisis modal kerja, analisis resiko kredit, analisis profitabilitas, asumsi klasik meliputi uji normalitas, uji multikolinearitas, uji heteroskedastisitas, uji autokorelasi, analisis regresi linear berganda, uji t dan uji F. Hasil penelitian ini menunjukan bahwa 1) Modal kerja berpengaruh positif terhadap profitabilitas. 2) Tidak terdapat pengaruh dan Signifikan antara Resiko Kredit terhadap Profitabilitas. 3) Secara bersama-sama atau secara simultan bahwa variabel Modal Kerja dan Resiko Kredit berpengaruh signifikan terhadap Profitabilitas. 4) faktor yang paling dominan yang mempengaruhi variabel Profitabilitas adalah Resiko Kredit.
\end{abstract}

Kata kunci: Modal Kerja, Resiko Kredit (NPL), Profitabilitas (ROA).

Abstract: The Effect of Working Capital and Credit Risk on Profitability PT. Bank Mandiri (Persero) Tbk. This study aims to determine the effect of working capital and credit risk on profitability. This type of research is a quantitative associative research. The research sample used for 10 years. Samples were taken using purposive sampling technique. The analytical methods used are working capital analysis, credit risk analysis, profitability analysis, classic assumptions include normality test, multicollinearity test, heteroscedasticity test, autocorrelation test, multiple linear regression method, $t$ test and $F$ test. Results this research shows that 1) working capital has a positive effect on profitability. 2) There is no significant and significant influence between Credit Risk and Profitability. 3) Together or simultaneously that the Working Capital and Credit Risk variables have a significant effect on profitability. 4) the most dominant factor influencing the profitability variable is Credit Risk.

Keywords: Working Capital, Credit Risk (NPL), Profitability (ROA).

\section{PENDAHULUAN}

Salah satu tulang punggung perekonomian dalan suatu Negara adalah sektor keuangan. Sektor perbankan merupakan salah satu sektor keuangan yang memegang peranan penting dan berpengaruh bagi perekonomian setiap Negara, tidak terkecuali Indonesia. Para pelaku perbankan menyadari bahwa dalam menjalankan fungsi jasa-jasa keuangan bank berada pada bisnis 


\section{Nominal: Barometer Riset Akuntansi dan Manajemen}

P-ISSN: 2303-2065 E-ISSN: 2502-5430

Volume 9 No 1 (2020)

yang beresiko besar. Resiko dalam

maka akan menjadi penyebab utama perbankan yaitu suatu kondisi yang sulit bagi kegagalan bank dalam menjalankan sebuah bank yang Nampak dalam bidang keuangan maupun bidang lainnya, sehingga bank tidak dapat beroperasi dengan normal atau bahkan menjadi bankrut, (Sudirman, 2000:198).

Industri perbankan merupakan industri yang syarat dengan resiko, karena melibatkan pengelolaan uang masyarakat dan diputar dalam bentuk berbagai investasi seperti pemberian kredit, pembelian suratsurat berharga dan penanaman modal dan lain sebagainya.

Kegiatan opersional bank dapat berjalan dengan lancar apabila bank tersebut memiliki modal yang cukup, sehingga pada saat-saat kritis, bank tetap dalam posisi aman karena memiliki cadangan modal di Bank Indonesia. Modal merupakan faktor yang sangat penting bagi kemajuan dan perkembangan bank, serta menjaga kepercayaan nasabah. Modal kerja sangat berpengaruh bagi suatu bank. Adanya modal kerja yang cukup memungkinkan suatu bank dalam melaksanakan kegiatannya tidak mengalami kesulitan serta hambatan yang akan timbul. Adanya modal kerja yang berlebihan menunjukkan adanya dana yang tidak produktif dan hal ini memberikan kerugian karena dana yang tersedia tidak dikelola secara efektif dalam kegiatan bank, dan sebaliknya jika kekurangan modal kerja aktivitasnya.

Bunga kredit merupakan fasilitas utama perbankan, karena bunga kredit merupakan sumber pendapatan terbesar bagi sektor perbankan. Setiap pemberian kredit yang dilakukan bank selalu terdapat resiko kredit (Non Performing Loan) yang sebanding dengan besarnya resiko kredit yang terdapat di Bank Mandiri.

PT. Bank Mandiri (Persero) Tbk merupakan leburan dari empat Bank pemerintah yaitu Bank Bumi Daya, Bank Dagang Negara, Bank Ekspor Impor Indonesia dan Bank Pembangunan Indonesia. Sebagai salah satu bank yang mempunyai visi untuk menjadi Lembaga Keuangan Indonesia yang di kagumi, tangguh, dan selalu progresif maka PT. Bank Mandiri harus dapat menjaga kinerja keuangannya dengan baik terutama tingkat profitabilitas bank itu sendiri. Peranan bank mandiri sebagai lembaga keuangan tidak terlepas dari masalah resiko kredit, pemberian kredit yang dilakukan oleh bank mengandung resiko yang berupa tidak lancarnya pembayaran atau pengembalian kredit yang diberikan oleh pihak bank kepada debitur dalam tempo waktu tertentu. Kredit bermasalah dapat diukur dari kolektibilitas dengan kriteria kurang lancar atau macet. Kemacetan fasilitas kredit disebabkan oleh 
beberapa faktor, yaitu faktor eksternal, faktor internal dari pihak perbankan dan faktor internal dari pihak nasabah. Bank dapat menjalankan operasinya dengan baik jika mempunyai NPL dibawah 5\% yang berarti semakin tinggi rasio NPL maka akan semakin buruk kualitas kredit bank yang menyebabkan jumlah kredit bermasalah semakin besar yaitu kerugian yang disebabkan oleh tingkat pengembalian kredit yang macet.

\section{Menurut Rivai}

menjelaskan tentang proses penerapan manajemen resiko yaitu:

1. Pengawasan aktif Dewan Komisaris dan Direksi

a. Komisaris bertanggung jawab dalam melakukan persetujuan dan peninjauan berkala.

b. Direksi bertanggungjawab untuk mengimplementasikan strategi dan mengembangkan kebijakan dan prosedur.

c. Bank harus mengidentifikasikan, mengelola, dan memastikan risiko kredit yang melekat pada seluruh produk dan aktivitas baru.

2. Bank harus memiliki satuan kerja yang melakukan review untuk menetapkan kolektabilitas.

3. Bank harus memastikan efisiensi dan efektivitas operasional administrasi kredit, akurasi dan ketepatan waktu informasi, pemisahan fungsi yang layak, kelayakan pengendalian seluruh back officer, dan kepatuhan terhadap kebijakan dan prosedur intern.

4. Bank mendokumentasikan seluruh informasi dalam arsip.

5. Penetapan limit.

a. Bank harus menggambarkan faktor yang dapat mempengaruhi penetapan limit resiko kredit.

b. Bank harus menetapkan limit untuk seluruh nasabah sebelum melakukan transaksi.

c. Limit untuk satu nasabah dapat di dasarkan atas hasil analisis data.

d. Penetapan limit risiko kredit harus di dokumentasikan secara lengkap.

6. Proses identifikasi, pengukuran, pemantauan, dan pengendalian risiko kredit serta sistem informasi manajemen risiko.

a. Identifikasi risiko kredit.

b. Bank harus mengidentifikasi risiko kredit yang melekat pada seluruh produk dan aktifitasnya.

c. Bank harus memiliki prosedur tertulis yang memungkinkan untuk sentralisasi exponsure on balance sheet dan off sheet yang mengandung resiko kredit dari setiap nasabah, dan mengenai faktafakta, sifat-sifat serta hubungan antar fenomena yang diselidiki.

Kemampuan profitabilitas dijadikan 
sebagai alat ukur yang professional dalam suatu lembaga keuangan yang dapat mengetahui suatu perbandingan data-data keuangan pada pos laporan keuangan. Profitabilitas bank mempunyai kemampuan untuk menghasilkan keuntungan dari hasil kinerja bisnis bank. Return On Asset. Merupakan rasio keuangan sederhana yang menjadikannya daya tarik beberapa pihak tertentu, seperti pemegang saham, kreditur, investor, pemerintah serta pihak lainnya. Menurut (Hassan, 2003) profitabilitas merupakan ukuran spesifik dari perfomance sebuah bank, dimana profit merupakan tujuan dari manajemen perusahaan dengan memaksimalkan nilai dari para pemegang saham, optimalisasi dari berbagai tingkat pengembalian dan meminimalisir resiko yang ada.

Berikut hasil pengamatan pada laporan keuangan PT. Bank Mandiri (Persero) Tbk yang berupa laporan Total Aset, Kredit Bermasalah, dan Laba Bersih dari tahun 2009-2018 (10 tahun) yang di paparkan menggunakan grafik.

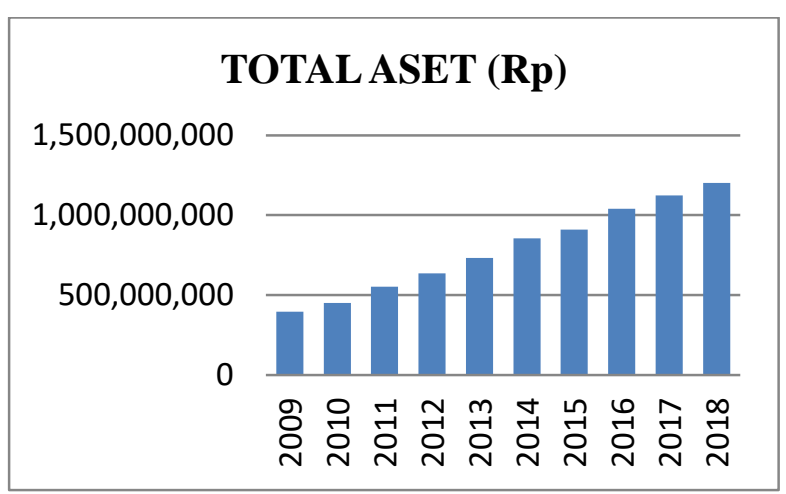

Sumber : data sekunder diolah, 2020

Gambar 1 : Grafik aktiva lancar
Dari gambar grafik diatas, terlihat bahwa aktiva lancar pada PT. Bank Mandiri (Persero) Tbk mengalami peningkatan dari tahun ke tahun dengan peningkatan tertinggi di tahun 2018 sebesar Rp. 1.202.252.094 dan paling rendah di tahun 2009 sebesar Rp. 394.616.604.

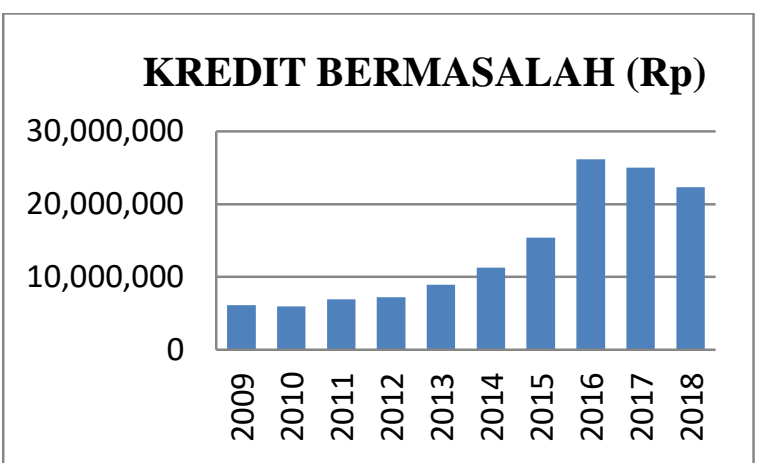

Sumber: data sekunder diolah, 2020 Gambar 2: Grafik Kredit Bermasalah

Dari gambar grafik diatas menunjukan bahwa Kredit Bermasalah PT. Bank Mandiri (Persero) Tbk mengalami fluktuatif yang di sebabkan karena pinjaman kredit yang diberikan oleh PT. Bank Mandiri (Persero) Tbk kepada nasabah mengalami ketidaklancaran dalam pembayaran seperti, pembayaran pokok pinjaman dan bunga pinjaman.

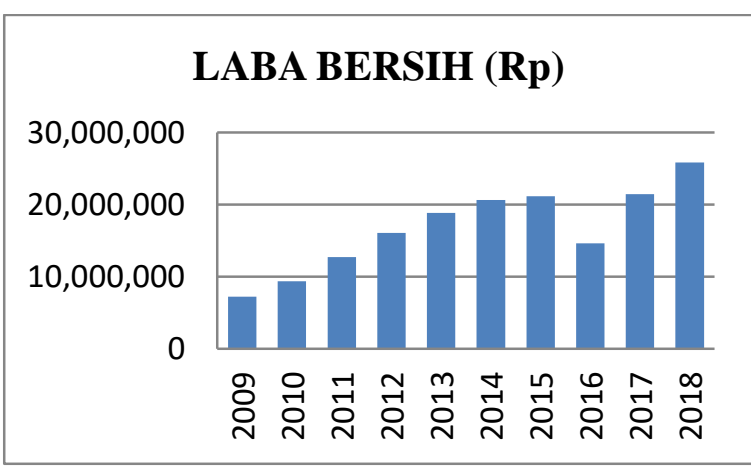

Sumber : data sekunder diolah 2020

Gambar 3 : Grafik Laba Bersih 
Dari gambar grafik di atas menunjukan bahwa Laba Bersih yang diperoleh mengalami fluktuatif (kenaikan dan penurunan). Hal ini disebabkan oleh adanya peningkatan beban operasional dari kegiatan perusahaan dan kurangnya pendapatan operasional yang diperoleh PT. Bank Mandiri (Persero) Tbk.

Berdasarkan hasil penelitian sebelumnya terhadap masing-masing variabel, penelitian mengenai pengaruh variabel resiko kredit terhadap profitabilitas yang di lakukan oleh Suherman (2016) mendapatkan hasil bahwa resiko kredit secara signifikan berpengaruh negatif terhadap profitabilitas, sedangkan Hasil temuan di dukung oleh hasil penelitian sebelumnya yang dilakukan oleh Anggriani (2014) pada perusahaan farmasi yang juga mendapatkan hasil bahwa modal kerja berpengaruh secara signifikan terhadap profitabilitas (ROA). Selain itu hasil penelitian yang dilakukan oleh Anggriani (2014) juga menyatakan bahwa perputaran persediaan berpengaruh secara signifikan terhadap profitabilitas (ROA).

Bedasarkan uraian dari latar belakang di atas, maka penulis tertarik untuk melakukan penelitian dengan judul: "Pengaruh Modal Kerja dan Resiko Kredit Terhadap Profitabilitas Pada PT. Bank Mandiri (Persero) Tbk".

\section{KAJIAN LITERATUR}

1. Pengertian Bank

Menurut Kasmir (2012:12) bank merupakan lembaga keuangan yang kegiatannya menghimpun dana dari masyarakat dalam bentuk simpanan kemudian menyalurkan kembali ke masyarakat, serta memberikan jasa-jasa kepada bank lainnya. Kegiatan-kegiatan Bank pada umumnya yaitu:

a. Menghimpun dana dari masyarakat dalam bentuk simpanan giro, tabungan maupun deposito.

b. Menyalurkan dana kepada masyarakat dalam bentuk kredit.

c. Memberikan jasa-jasa bank lainnya seperti, transfer, inkaso, kliring, safe deposit box, bank card dan lain-lain.

2. Modal Kerja

Menurut Munawir (2010:115) modal kerja merupakan salah satu bagian dari asset yang ada dalam perusahaan. Modal merupakan faktor yang sangat penting dalam perusahaan. Tanpa modal kerja yang cukup, suatu perusahaan akan kehilangan kesempatan untuk meningkatkan kuantitas dan kualitas produk yang di hasilkan. Besarnya modal

kerja tergantung pada jenis bisnis, akan tetapi umumnya nilai modal kerja suatu perusahaan lebih dari $50 \%$ dari jumlah harta, maka di perlukan pengelolaan yang 
serius. Besarnya modal kerja dapat dihitung dengan rumus:

Modal Kerja $=$ Aktiva Lancar - Hutang Lancar

Manfaat modal kerja mampu membiayai pengeluaran atau operasional perusahaan sehari-hari. Dengan modal kerja yang cukup akan membuat perusahaan beroperasi secara ekonomis dan efisien serta tidak mengalami kesulitan keuangan. Manfaat modal kerja adalah sebagai berikut:

a. Melindungi perusahaan terhadap krisis modal kerja karena turunnya nilai dari aktiva lancar

b. Memungkinkan untuk dapat membayar semua kewajiban-kewajiban tepat pada waktunya.

c. Memungkinkan untuk memiliki persediaan dalam jumlah yang cukup untuk melayani para nasabah atau konsumen.

d. Memungkinkan bagi perusahaan untuk memberikan syarat kredit yang lebih menguntungkan kepada para nasabah/konsumen

e. Memungkinkan bagi perusahaan untuk dapat beroperasi dengan lebih efisien karena tidak ada kesulitan untuk memperoleh barang ataupun jasa yang dibutuhkan.

3. Resiko Kredit

Menurut Siamat (2004:92) resiko kredit atau default risk merupakan suatu resiko akibat kegagalan atau ketidakmampuan mengembalikan jumlah pinjaman yang diperoleh dari bank beserta bunganya sesuai dengan jangka waktu yang telah ditentukan atau di jadwalkan. Ketidakmampuan nasabah memenuhi perjanjian kredit yang di sepakati oleh kedua belah pihak, secara teknis keadaan tersebut merupakan default.

Sedangkan menurut Hardanto (2006:106), mengemukakan bahwa resiko kredit adalah resiko kerugian yang dengan peluang gagal memenuhi kewajiban pada saat jatuh tempo. Dengan kata lain, resiko kredit adalah resiko karena peminjam tidak membayar utangnya. Resiko kredit timbul dari beberapa kemungkinan sebagai berikut:

a. Debitur tidak dapat melunasi utangnya.

b. Obligasi yang di beli bank, tidak membayar kupon dan pokok utang.

c. Terjadinya Non Perfomance (gagal bayar) dari semua kewajiban antara bank dengan pihak lain.

Resiko kredit di proksikan Non Performing Loan (NPL). Menurut Kasmir (2013:155) Net Performing Loan merupakan kredit bermasalah atau kredit macet yang didalamnya terdapat hambatan yang disebabkan oleh Dua unsur, yakni dari pihak perbankan dalam menganalisis maupun dari pihak nasabah yang dengan sengaja atau tidak sengaja dalam kewajibannya tidak melakukan pembayaran atas peminjaman 
yang telah dilakukan. Besarnya nilai NPL suatu bank dapat dihitung dengan rumus:

$$
N P L=\frac{\text { Kredit Bermasalah }}{\text { Total Kredit }} \times 100 \%
$$

Akibat dari Non Performing Loan (NPL) bagi pihak perbankan yaitu hilangnya kesempatan untuk mendapatkan pendapatan dari penyaluran kredit yang menyebabkan tingkat pengembalian laba dalam hal ini Return On Asset yang menurun.

4. Profitabilitas

$$
\text { Menurut Kasmir (2012:196) Rasio }
$$

Profitabilitas merupakan rasio untuk menilai kemampuan perusahaan perbankan dalam mencari keuntungan, sedangkan menurut Irham Fahmi (2012:135) profitabilitas merupakan rasio yang mengukur efektivitas manajemen secara keseluruhan yang ditunjukkan oleh besar kecilnya tingkat keuntungan yang diperoleh dalam hubungannya dengan penjualan maupun invesastasi. Semakin baik rasio profitabilitas, maka semakin baik

menggambarkan kemampuan tingginya perolehan keuntungan perusahaan.

5. Pengaruh Modal Kerja Terhadap Profitabilitas.

Menurut Harahap (2010) modal kerja yang cukup maka kebutuhan ataupun kegiatan perusahaan dalam menjalankan operasionalnya dapat terpenuhi sehingga profitabilitas optimal.

Menurut pendapat penulis jika perusahaan atau perbankan memiliki modal kerja dalam jumlah yang besar kemungkinan kesempatan untuk mendapatkan laba yang besar akan menurun dan pada akhirnya berdampak pada penurunan profitabilitas. Sebaliknya jika perusahaan atau perbankan ingin memaksimalkan profitabilitas, kemungkinan dapat mempengaruhi tingkat likuiditas perusahaan.

6. Pengaruh Resiko Kredit Terhadap Profitabilitas.

Kredit macet atau kredit bermasalah kerap terjadi karena pihak bank terlalu cenderung mengejar target penyaluran kredit tanpa memperhatikan analisis kredit. Semakin tinggi resiko kredit yang bermasalah akibat pembayaran pokok pinjaman dan bunga pada bank, maka secara langsung akan berdampak pada penurunan kinerja perbankan. Hal tersebut menunjukkan semakin tinggi Net Perfoming Loan maka semakin rendah profitabilitas yang terdapat pada bank tersebut. Pernyataan ini sesuai dengan hasil penelitian yang dilakukan oleh (Limpaphayom dan Polwitoon, 2004) menunjukan bahwa Non Performing Loan (NPL) berpengaruh positif terhadap Return On Assets (ROA) 


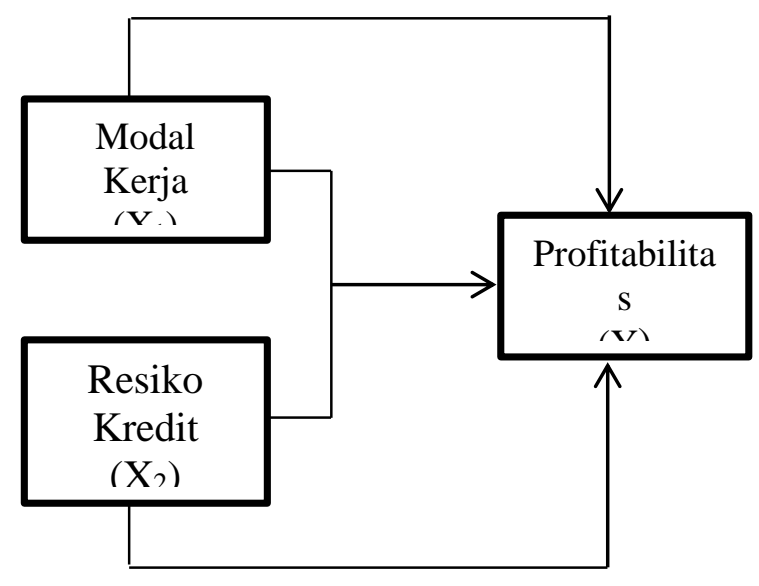

Gambar 4: Kerangka Berpikir

H1: Terdapat pengaruh yang signifikan antara Modal Kerja terhadap Profitabilitas

$\mathrm{H} 2$ : Terdapat pengaruh yang signifikan secara parsial antara Resiko Kredit terhadap Profitabilitas

H3: Terdapat pengaruh secara simultan antara Modal Kerja dan Resiko Kredit terhadap Profitabilitas

H4: Faktor yang paling dominan yang mempengaruhi profitabilitas yaitu resiko kredit.

\section{METODE PENELITIAN}

\section{Jenis Penelitian}

Jenis Penelitian ini termasuk penelitian asosiatif, yaitu penelitian yang bertujuan untuk mengetahui hubungan antara dua variabel atau lebih, (Sugiyono, 2011:36).

Dalam hal ini penelitian dilakukan untuk mengetahui pengaruh antara modal kerja dan resiko kredit terhadap profitabilitas pada PT. Bank Mandiri (Persero) Tbk.

\section{Waktu dan Tempat Penelitian}

Penelitian ini di lakukan di PT. Bank Mandiri (Persero) Tbk melalui situs www.bankmandiri.co.id.Penelitian dilakukan pada bulan Desember 2019 hingga Maret 2020.

\section{Subjek Penelitian}

Populasi adalah wilayah generalisasi yang terdiri atas obyek/subyekyang mempunyai kualitas dan karakteristik tertentu yang di tetapkan oleh peneliti untuk di pelajari dan kemudian ditarik kesimpulannya, (Sugiyono, 2011:80).

Adapun Populasi dalam penelitian ini adalah data laporan keuangan neraca terdiri atas aktiva lancar, total Liabilitas, total asset, dan laporan laba rugi terdiri atas laba sebelum pajak dan kolektibilitas kredit bermasalah terdiri atas kredit kurang lancar, diragukan, macet dan total kredit pada PT. Bank Mandiri (Persero) Tbk selama 16 tahun (2003-2018). dari populasi diatas maka yang akan di jadikan sampel adalah laporan keuangan PT. Bank Mandiri (Persero) Tbk dari tahun 2009-2018 (10 tahun). Sampling penelitian yang digunakan dalam penelitian ini adalah Purposive Sampling Alasan menggunakan Purposive Sampling. yaitu karena ketersediaan data yang dibutuhkan dalam penelitian mudah diakses dan datadatanya teupdate pada financial report PT Bank Mandiri (Persero) Tbk 


\section{Instrumen Penelitian}

Instrumen penelitian adalah suatu alat yang digunakan mengukur fenomena alam maupun sosial yang diamati, secara spesifik semua fenomena ini disebut variabel penelitin (Sugiyono 2011:102). Instrumen penelitian yang digunakan yaitu daftar tabel berupa data laporan keuangan terdiri atas data modal kerja, resiko kredit, dan profitabilitas.

\section{Data dan Teknik Pengumpulan}

Data yang digunakan dalam penelitian ini adalah data sekunder yang berupa laporan keuangan PT. Bank Mandiri (Persero) Tbk. Laporan keuangan tersebut dapat di akses melalui situs yaitu www.bankmandiri.co.id.

Teknik pengumpulan data yang digunakan adalah studi pustaka dan dokumentasi.

\section{Teknik analisa data}

Teknik analisa yang digunakan yaitu uji asumsi klasik, regresi linier berganda, koefisien korelasi berganda, koefisien determinasi berganda, uji t dan uji F.

\section{HASIL PENELITIAN DAN}

\section{PEMBAHASAN}

Hasil Uji t dan Uji F

H1 diterima karena nilai thitung sebesar 3,057 dan $t_{\text {tabel }}$ sebesar 2,365 dengan nilai signifikan 0,018 yang berarti kurang dari 0,05. Artinya terdapat pengaruh yang signifikan secara parsial antara Modal Kerja dan Resiko Kredit terhadap Profitabilitas pada PT. Bank Mandiri (Persero) Tbk.

H2 ditolak karena nilai thitung sebesar 13,234 dan $t_{\text {tabel }}$ sebesar 2,365 dengan nilai signifikan 0,000 kurang dari 0,05.

Tabel 1. Hasil Analisis Uji t

\begin{tabular}{clcc}
\hline $\begin{array}{c}\text { Variabel } \\
\text { Independen }\end{array}$ & $\begin{array}{c}\text { Variabel } \\
\text { Dependen }\end{array}$ & thitung & Sig. \\
\hline Modal & Profitabilita & 3.057 & 0,018 \\
Kerja $\left(\mathrm{X}_{1}\right)$ & s (Y) & & \\
Resiko & Profitabilita & -13.234 & 0,000 \\
Kredit $\left(\mathrm{X}_{2}\right)$ & s (Y) & & \\
\hline
\end{tabular}

Sumber : Data Sekunder diolah 2020

Artinya tidak terdapat pengaruh dan signifikan antara Resiko Kredit terhadap Probabilitas pada PT. Bank Mandiri (Persero) Tbk.

Tabel 2. Hasil Analisis Uji F

\begin{tabular}{|c|c|c|c|}
\hline $\begin{array}{c}\text { Variabel } \\
\text { Independe } \\
n(\mathrm{X})\end{array}$ & $\begin{array}{c}\text { Variabel } \\
\text { Dependen } \\
\text { (Y) }\end{array}$ & $F_{\text {hitung }}$ & Sig \\
\hline Modal & Profitabilita & 91,73 & 0,00 \\
\hline $\begin{array}{c}\text { Kerja dan } \\
\text { Resiko } \\
\text { Kredit }\end{array}$ & $\mathrm{s}$ & 5 & 0 \\
\hline
\end{tabular}

Sumber : Data Sekunder diolah 2020

H3 di terima karena nilai $F_{\text {hitung }}$ sebesar 91,735 dan $F_{\text {tabel }}$ sebesar 4,737 dengan nilai signifikan 0,000 kurang dari 0,05 . Artinya terdapat pengaruh secara simultan antara Modal Kerja dan Resiko Kredit terhadap Profitabilitas pada PT. Bank Mandiri (Persero) Tbk.

H4 diterima Nilai Koefisien determinasi Modal Kerja ( $\left.\mathrm{X}_{1}\right)$ sebesar 0,044 atau $44 \%$ dan nilai Koefisien Determinasi Resiko Kredit $\left(\mathrm{X}_{2}\right)$ sebesar 0,914 atau 91,4\%. 
Artinya faktor yang paling dominan yang mempengaruhi Profitabilitas pada PT. Bank Mandiri (Persero) Tbk yaitu Resiko Kredit

Tabel 3. Hasil Output SPSS Koefisien

Determinasi

\begin{tabular}{|c|c|c|c|c|}
\hline \multicolumn{5}{|c|}{ Model Summary } \\
\hline $\begin{array}{c}\text { Mode } \\
1\end{array}$ & $\mathrm{R}$ & $\begin{array}{c}\mathrm{R} \\
\text { Square }\end{array}$ & $\begin{array}{c}\text { Adjuste } \\
\text { d R } \\
\text { Square }\end{array}$ & $\begin{array}{l}\text { Std. } \\
\text { Error of } \\
\text { the } \\
\text { Estimat } \\
\mathrm{e}\end{array}$ \\
\hline 1 & $.209^{\mathrm{a}}$ & .044 & -.076 & .37041 \\
\hline \multicolumn{5}{|c|}{ a. Predictors: (Constant), MODAL KERJA } \\
\hline \multicolumn{5}{|c|}{ Model Summary } \\
\hline
\end{tabular}

Std.

$\begin{array}{ccccc}\text { Mode } & & \mathrm{R} & \begin{array}{c}\text { Adjuste } \\ \mathrm{d} \mathrm{R}\end{array} & \begin{array}{c}\text { Error of } \\ \text { the } \\ 1\end{array} \\ & & \text { Square } & \begin{array}{c}\text { Square } \\ \text { Estimat }\end{array}\end{array}$

e

$\begin{array}{lllll}1 & .956^{\mathrm{a}} & .914 & .903 & .11095\end{array}$

a. Predictors: (Constant), RESIKO KREDIT Sumber: Output SPSS versi 20.0

\section{SIMPULAN DAN SARAN}

\section{Simpulan}

Penelitian ini menunjukkan bahwa terdapat pengaruh yang signifikan secara parsial antara Modal Kerja pada PT. Bank Mandiri (Persero) Tbk, tidak terdapat pengaruh dan signifikan antara Resiko Kredit "NPL" terhadap Profitabilitas "ROA" pada PT. Bank Mandiri (Persero) Tbk, terdapat pengaruh secara simultan antara Modal Kerja dan Resiko Kredit "NPL" terhadap Profitabilitas (ROA) pada PT. Bank Mandiri (Persero) Tbk dan faktor yang paling dominan yang mempengaruhi Profitabilitas (ROA) pada PT. Bank Mandiri (Persero) Tbk yaitu Resiko Kredit (NPL).

\section{Saran}

Bagi penelitian selanjutnya, agar menggunakan model analisis yang berbeda dengan menambahkan teori pendukung atau variabel penelitian dan jumlah data sampel penelitian.

Bagi perusahaan PT. Bank Mandiri (Persero) Tbk untuk lebih memperhatikan tingkat analisis kreditnya di sesuaikan dengan anggunan kreditur.

\section{DAFTAR PUSTAKA}

Anggraeni, D. (2014). Pengaruh Modal Kerja Dan Perputaran Persediaan Terhadap Profitabilitas (ROA). (Pada Perusahaan Farmasi Yang Terdaftar Di Bursa Efek Indonesia Priode 2008-2013). Jurnal Ekonomi (Online). 3(2): 2442-4951.

Fahmi, I. (2012). Analisis kinerja keuangan. Bandung: Alfabeta.

Hassan. (2003). Buku Pintar Pasar Modal Indonesia (The Intelligent Guide to Indonesian Capital Market). Mediasoft Indonesia, First Edition.

Harahap, S. S. (2010). Analisis kritis laporan keuangan. Jakarta: Rajawali Pers.

Hardanto, S. S. (2006). Manajemen Resiko Bagi Bank Umum. Elex Media Komputindo.

Kasmir, (2012). Manajemen Perbankan. Edisi Revisi. Jakarta: PT. RajaGrafindo Persada. 
Kasmir, (2012). Analisis Laporan Keuangan. Jakarta: PT. Raja Grafindo Persada.

Kasmir, (2013). Analisis Laporan Keuangan. Edisi Pertama. Jakarta: Rajawali Pers.

Laporan Keuangan PT Bank Mandiri (Persero) Tbk. Periode (2009-2018). Diakses (2019) dari http://www.bankmandiri.co.id.

Limpaphayom, P., \& Polwitoon, S. (2004). Bank relationship and firm performance: evidence from Thailand before the Asian financial crisis. Journal of Business Finance \& Accounting, 31(9-10), 1577-1600.

Munawir, S. (2010). Analisa Laporan Keuangan Edisi 4. Penerbit Liberty, Yogyakarta.

Rivai, V. (2007). Bank and Financial Institution Management Conventional and Sharia System. jakarta: PT Raja Grafindo Persada.

Siamat, D. (2004). Manajemen Lembaga Keuangan, Edisi Keempat. Jakarta: Lembaga Penerbit Fakultas Ekonomi Universitas Indonesia.

Sudirman, (2000). Manajemen Perbankan. Denpasar: PT. BP Denpasar

Sugiyono, (2011). Metode Pen elitian Kuantitatif Kualitatif dan R\&D. Bandung: Alfabeta.

Suherman, U. D. (2016). Pengaruh Resiko Kredit Terhadap Profitabilitas (Studi Kasus Pada Bank Jabar Banten Syariah Periode 2010-2015). ADLIYA: Jurnal Hukum dan Kemanusiaan, 10(2), 201216. 